\title{
Temporal and Spatial Distribution of Enterobius vermicularis (Nematoda: Oxyuridae) in the Prehistoric Americas
}

\author{
Karl J. Reinhard',*, Adauto Araújo², Johnica J. Morrow ${ }^{1}$ \\ ${ }^{1}$ Pathoecology Laboratory, School of Natural Resources, University of Nebraska-Lincoln, Lincoln, Nebraska, 68583-0962, USA; '2Laboratório de \\ Paleoparasitologia, Departamento de Endemias Samuel Pessoa/Escola Nacional de Saúde Pública Sergio Arouca/Fundação Oswaldo Cruz \\ (DENSP/ENSP/FIOCRUZ), Rua Leopoldo Bulhões, Rio de Janeiro, RJ, 21041-210, Brazil
}

\begin{abstract}
Investigations of Enterobius sp. infection in prehistory have produced a body of data that can be used to evaluate the geographic distribution of infection through time in the Americas. Regional variations in prevalence are evident. In North America, 119 pinworm positive samples were found in 1,112 samples from 28 sites with a prevalence of $10.7 \%$. Almost all of the positive samples came from agricultural sites. From Brazil, 0 pinworm positive samples were found in 325 samples from 7 sites. For the Andes region, 22 pinworm positive samples were found in 411 samples from 26 sites for a prevalence of 5.3\%. Detailed analyses of these data defined several trends. First, preagricultural sites less frequently show evidence of infection compared to agricultural populations. This is especially clear in the data from North America, but is also evident in the data from South America. Second, there is an apparent relationship between the commonality of pinworms in coprolites and the manner of constructing villages. These analyses show that ancient parasitism has substantial value in documenting the range of human behaviors that influence parasitic infections.
\end{abstract}

Key words: Enterobius, archaeological parasitology, Oxyuridae, pinworm, Americas, review

\section{INTRODUCTION}

Since 1997, and especially after 2000, the directorships of the Laboratório de Paleoparasitologia, Escola Nacional de Saúde Pública Fundação Oswaldo Cruz (ENSP/FIOCRUZ), Brazil, and the Pathoecology Laboratory at the University of Nebraska-Lincoln (UNL), USA committed to exchange personnel in an intense collaboration to define the origin and distribution of parasitism in the Americas. During this time, UNL hosted ENSP/FIOCRUZ graduate students and postdocs for a total of 38 months and ENSP/FIOCRUZ hosted UNL researchers for 36 months. One main project beginning in 2001 was to define the distribution and pathoecology of the human pinworm, Enterobius vermicularis, in the prehistoric Americas. Up until 2000, the research on this species had a North American focus. This species was unexpectedly rare in South Ameri-

\footnotetext{
- Received 27 May 2016, revised 31August 2016, accepted 11 September 2016.

*Corresponding author (kreinhard1@unl.edu)

(C) 2016, Korean Society for Parasitology and Tropical Medicine

This is an Open Access article distributed under the terms of the Creative Commons Attribution Non-Commercial License (http://creativecommons.org/licenses/by-nc/4.0) which permits unrestricted non-commercial use, distribution, and reproduction in any medium, provided the original work is properly cited.
}

ca. In 2001, with funding from the Fulbright Commission, we focused on the analysis of coprolites collected from South America and curated in both laboratories. Although the analysis included a search for all helminth species, E. vermicularis was of special interest. Gradually, some of the data collected between 2001 and 2007 were published. The published studies focused only on positive samples. To gain a better picture of the distribution of the pinworm, we are presenting here a complete review, including negative studies. The presence and absence of data, as well as prevalence values, provided a picture of the conditions of prehistoric life that limited or exacerbated pinworm infections in the Americas.

Pinworm species (E. vermicularis and Enterobius greggori) are common human parasites in all habitable parts of the world. They have a long evolutionary history with humans and cause little pathology. Thus, from a medical perspective, they are of reduced interest relative to more pathogenic human helminth species.

Pinworms have singular importance in Americas paleopathology and pathoecology. They are nearly ubiquitous, are prolific in crowded conditions, and are easily recoverable from archaeological sites if coprolites and mummies are preserved. 
Thus, they are very good indicators of changes in health that results from cultural developments. Herein, we reviewed the evidence of E. vermicularis infection in the prehistoric Americas to show how pinworms, so mundane in the medical world, have great importance in tracing the influence of cultural changes on human biology.

\section{MATERIALS AND METHODS}

We analyzed 151 coprolites from the Andes as part of a parasitological survey of coprolites and mummies from southern Peru and northern Chile. In addition, 280 coprolites from a Brazilian Central Plains cave were analyzed. We used both the Callen method and the Lutz method [1-3]. These methods have been shown to be equivalent for documenting prevalence [1].

Our previous studies of helminth remains from archaeological sites included the western USA, Central Mexico, the central and southern coast of Peru, the northern region of Chile, and northeastern Brazil. We have primarily analyzed coprolites from these areas, but mummies have been another focus of our research, especially in Chile and Peru. In addition, other parasitologists have analyzed coprolites and mummies from these regions as well as from Greenland and the Southeastern USA [13]. At this point, over 1,800 coprolite and mummy samples have been analyzed, inclusive of published studies by other authors. From 2007 onwards, we focused our laboratories' efforts on the analysis of samples from north-central Mexico. Many of these data are presented in this paper for the first time.

\section{Dating}

The value of archaeologically-derived data relates to the accuracy of dating and security of context [1-3]. Many dating methods are used. Chronometric dates are derived from biological, chemical, or physical tests of materials. For example, in the southwestern United States, there is a good sequence of tree-ring dates (dendrochronology) for archaeological time periods that forms a sound biological dating basis for this region. The most common chemical test for archaeological deposits is radiocarbon analysis of biogenic remains such as wood, charcoal, or bone. The most common physical analysis is paleomagnetism, which can be used to date hearths and other heated areas in an archaeological site. In some regions, artifacts, especially ceramics, can be used to date mummies and coprolites. The artifact styles are dated by association with chronometric data (radiocarbon analysis, tree-rings, etc.).

\section{Sampling}

A key problem for us was the identification of human vs nonhuman coprolites, when coprolites are not associated with mummies or skeletons. For many years, attempts have been made to use chemical tests to identify human coprolites, with mixed results $[2,3]$. For our research, it has been necessary to gain a familiarity with the fecal morphology of animals within our study areas. For northeastern Brazil, Chame [4] completed the basic research in indigenous animal scatology that allowed identification of animal vs human coprolites. For the Atacama Desert, the problem is reduced because of the generally lower diversity of animals that are indigenous to the region. In general, when coprolites are well preserved, it is possible to distinguish human feces from non-human feces with 2 exceptions. In all research areas, dogs produce feces that can be confused with human feces. In Arizona, feces from javalina (Tayassu tajacu and Tayassu pecari) can be confused with humans. Up to now, only by analysis of fecal constituents, such as hair and dietary residue, can coprolites from these species be differentiated with confidence from those of humans.

For coprolite analysis, it is important to diversify samples from archaeological sites [1-3]. For our purposes, context is especially important. Context refers to the archaeological location of finds in association with distinct prehistoric constructions, such as houses, burials, trash pits, latrines, plazas, etc. Archaeologists refer to the constructions as "features" and the contextual association is referred to as "provenience". Thus, the "provenience" of a coprolite can be in "context" of latrine "feature 3" in field notes. Considering the nature of proveniences and features is especially important for our work and generally we work with field notes or forms if we cannot be present in the field. It is desirable for the paleoepidemiological approach to maximize the diversity of our samples to ensure that as many separate defecations as possible are included in the study. This minimizes the possibility of sampling several defecations by 1 prehistoric individual over a short period of time. At some sites, many features contain feces. At such sites, it is best to analyze small samples of coprolites from as many features as possible. In this way, one is likely to sample a series of defecations by many individuals. Such a site is represented by Antelope House, Arizona, USA [5].

At other sites, large latrines were used for many years. Such features may contain hundreds to thousands of coprolites. If possible, it is good to have first-hand experience at such sites. For example, Salmon Ruin, New Mexico, had such a latrine [5]. 
Examination of the latrine stratigraphy showed that the coprolites were concentrated in stratigraphic lenses. A "stratigraphic lens" is a relatively small, lenticular-shaped stratum with its longest axis in the horizontal plane. These typically represent single deposits made by prehistoric people. At Salmon Ruin, the lenses were about the volume of a prehistoric basket. This indicated that feces were brought to the latrine from other rooms in household containers. Ideally, the sampling strategy would have been to sample a coprolite from each lens. However, this was not done in the field. Therefore, to diversify the sample as much as possible, coprolites were sampled from alternate units in every other grid square. Since the site was excavated in $1 \mathrm{~m}$ horizontal grid squares in $10 \mathrm{~cm}$ vertical levels, the sampling strategy ensured that as many lenses as possible were sampled. Other sites, especially Archaic hunter-gatherer sites, exhibit a single latrine area in a cave that is intermittently used for literally thousands of years ("Archaic" refers to a preceramic, hunter-gatherer lifestyle that began about 8,000 years ago in North America).

Hinds Cave, Texas [6] and Dust Devil Cave, Utah [7] provide examples of such behavior. Sample diversity for such sites can be obtained by taking samples from as many strata as possible. In northeastern Brazil, Peru, and Chile, open sites (sites not in caves) are most common. Interesting defecation patterns are found in these regions. Sometimes, discrete coprolite aggregations are associated with specific features. In Peru and Chile, this includes latrines associated with house features. Therefore, sampling several latrines diversifies the sample. In shell mounds (large accumulations of shell, burials, and activity refuse), coprolites are found dispersed in the refuse. At 1 site, Paloma, near Lima, Peru, the coprolites were frequently found in large bivalves [8]. This ancient practice is very helpful in modern sampling because one can feel certain that a given bivalve contained 1 person's feces, uncontaminated by neighboring feces. At this site, coprolites were sampled from a variety of diverse proveniences, including the refuse areas, distinct strata, house floors, and burials. At another shell mound, the Ring Site, near Ilo, Peru, distinct, small lenses about 6 inches were found in stratigraphic sections of the site $[9,10]$. Each lens was derived from an individual coprolite. The lenses were sampled and their constituents were consistent with ancient feces of mummies from the area. Unfortunately, the Ring Site, the oldest site on the coast of southern Peru, was largely destroyed by construction [10].

Ideally, optimal diversity can be obtained by sampling mummies and burials. Fecal residue can be found in skeletons [1-3] and mummies contain fecal pellets that can be recovered and analyzed. The data recovered from mummy/skeleton contexts and non-mummy/skeleton contexts are not equivalent. One can be sure that coprolites recovered from mummies or skeletons are: 1) from humans, and 2) represent discrete infections if parasites are found. In contrast, with coprolites found in non-mummy/skeleton contexts there is often doubt as to how many individuals and defecations are represented by a coprolite series. Therefore, we usually prefer to use coprolites from non-mummy/skeleton contexts to gain an idea of the diversity and antiquity of parasites present in a region. Coprolites from mummies/skeletons provide an idea of the number of people infected at death. Therefore, they can be used in a comparative sense to evaluate variance in infection.

\section{Preservation}

Not all coprolites exhibit comparable preservation [11,12]. The preservation of coprolites can be assessed by examining the range of identifiable macroscopic and microscopic components. Macroscopic components typically include seeds, fibers, bone, chitin exoskeleton, charcoal, leaves, fruit skin, and woody tissue. Microscopic components include starch granules, pollen grains, silica phytoliths, calcium oxalate phytoliths, mites, hair, seed testa fragments, plant cells, nematode larvae, parasite eggs, and fungal spores [2]. By assessing the diversity of components present, one can assess the level of preservation and therefore the potential loss of parasite eggs and larvae. Coprolites from cave contexts are most often well-preserved with even the most delicate remains preserved. In contrast, coprolites from open sites exhibit less consistent preservation. In assessing the reliability of parasitology results, one must consider the preservation conditions of the coprolites $[11,12]$.

For pinworms, preservation can be highly variable. In rare cases, fragments of adult worms are found. Generally, eggs containing larvae are recovered. From archaeological sites that are not established in caves, eggs are more often recovered in fragmentary condition.

\section{SURVEY FINDINGS}

\section{South America}

The archaeological sites for which parasitological studies have been conducted were never summarized in a single arti- 
cle. Therefore, we are presenting brief descriptions of each site and a summary list (Tables 1,2).

Callen and Cameron [13] examined several coprolites from Huaca Prieta, Peru, including coprolites from the intestinal cavity of a burial dating to approximately 4,500 years ago by radiocarbon technique. Huaca Prieta was a prehistoric settle- ment at the Pacific Ocean coast in the Chicama Valley, north of Trujillo [10]. The exact number of coprolites analyzed was not published in this pioneer study. At least 1 sample was recovered from a burial. The site was occupied by hunter-gatherers with a mixed diet of terrestrial plants and marine animals. The coprolites were recovered from a cave and exhibited good

Table 1. Coprolite and mummy data accumulated from the Andes

\begin{tabular}{|c|c|c|c|}
\hline Locality & Reference & No. studied/No. positive & Dates (B.P.) \\
\hline Ring Site, Peru & (this analysis) & $6 / 0$ & $7,675 \pm 60-10,575 \pm 105$ \\
\hline Los Gavilanes, Peru & [14] & $1 / 22$ & $4,730-4,130$ \\
\hline Los Gavilanes, Peru & [14] & $22 / 0$ & $3,755-4,227$ \\
\hline Los Gavilanes, Peru & [14] & $8 / 0$ & mixed strata \\
\hline Tiliviche, Chile & [19] & $26 / 0$ & $6,110-3,950$ \\
\hline Paloma, Peru & (this analysis) & $20 / 0$ & 6,000 \\
\hline Morro, Chile & (this analysis) & $21 / 0$ & 6,000 to 4,000 \\
\hline Huaca Prieta, Peru & [13] & $? / 0$ & 4,500 \\
\hline "Cultura Azapa", Chile & [17] & $5 / 0$ & 2,700 \\
\hline Mono, Peru & (this analysis) & $1 / 28$ & 2,300 \\
\hline Caserones, Chile & [17] & $10 / 1$ & $2,400-1,200$ \\
\hline Pisco, Peru & [44] & $1 / 0$ & 1,500 \\
\hline Unnamed site & [14] & $3 / 0$ & circa 1,000 \\
\hline Chiribaya Alta, Peru & [15] & $1 / 30$ & $1,150-534$ \\
\hline San Geronimo, Peru & [15] & $8 / 0$ & $1,150-534$ \\
\hline Chribaya Baja, Peru & [15] & $11 / 0$ & $1,150-534$ \\
\hline San Geronimo \& Chribaya Baja, Peru & [16] & $29 / 0$ & $1,150-534$ \\
\hline Tulán, Chile & [18] & $11 / 16$ & $880-750$ \\
\hline Lluta Valley, Chile & [20] & $15 / 0$ & $900-700$ \\
\hline Lluta Valley, Chile & [20] & $5 / 20$ & $700-500$ \\
\hline Argentina Sacrafice & [21] & $1 / 1$ & 400 \\
\hline El Plomo, Chile & {$[22,45]$} & $1 / 0$ & 500 \\
\hline San Pedro de Atacama, Chile & (this analysis) & $48 / 0$ & various times \\
\hline Various sites, Peru and Chile & Hill, unpublished & $24 / 0$ & various time periods \\
\hline Various sites, Peru and Chile & [46] & $8 / 0$ & various time periods \\
\hline Antofogasta, Chile & (this analysis) [47] & $1 / 28$ & various prehistoric periods \\
\hline Total & Jorm positive sample & in 411 samples from & \\
\hline
\end{tabular}

Dating has been converted to the Before Present (B.P.) scale. By archaeological and geological convention, January 1, 1950 is the modern reference point for this scale.

Table 2. Coprolite and mummy data recovered from Brazil

\begin{tabular}{lccc}
\hline Locality & Reference & No. studied/No. positive & Dates (B.P.) \\
\hline Boqueirão da Pedra Furada, Piaú & {$[26,28]$} & $17 / 0$ & 7,230 \\
Boqueirão Soberbo, Varzelándia, Minas Gerais & {$[26]$} & $2 / 0$ & 4,905 \\
Gruta do Gentio II, Unai, Minas Gerais & {$[25]$} & $20 / 0$ & 3,490 \\
Gruta do Gentio II, Unai, Minas Gerais & (this analysis) & $278 / 0$ & 3,490 \\
Furna do Estrago, Pernambuco & {$[59]$} & $6 / 0$ & $1,730-1,610$ \\
Gruta do Gentio II, Unai, Minas Gerais & {$[24]$} & $1 / 0$ & 430 \\
Lapa do Boquete & {$[27]$} & $1 / 0$ & $530-930$ \\
Total & O pinworm positive samples were found in 325 samples from 7 sites \\
\hline
\end{tabular}

Dating has been converted to the Before Present (B.P.) scale. By archaeological and geological convention, January 1, 1950 is the modern reference point for this scale. 
preservation. No pinworm eggs were encountered although other helminth species were present.

Patrucco and colleagues [14] found pinworm eggs in 1 of 52 coprolites from the coastal site of Los Gavilanes in northcentral Peru. The site is located $3.2 \mathrm{~km}$ north of the Huarmey River and $0.5 \mathrm{~km}$ inland from the Pacific Ocean. The site was a Preceramic period (Late Archaic) seasonal occupation and storage area. The site had 2 distinct strata dated by radiocarbon technique to 4,730-4,130 years ago and 3,755-4,227 years ago, respectively. Twenty-two coprolites from each stratum were analyzed. In addition, 8 coprolites from mixed context of the 2 main strata were analyzed. They also included in their report mention of an analysis they did of an 'unnamed site' dated by artifact association to about 1,000 years ago. The coprolite preservation was good at this site. The 1 coprolite positive for E. vermicularis was in context with the older stratum, which was 4,730-4,130 years old.

We examined 28 coprolites from the Mono Site, Peru (unpublished data). This site is located near Paracas, Peru. It is dated to approximately 2,300 years ago by artifact association. To date, the data indicate that the site's inhabitants ate a variety of cultivated crops, marine fish, and marine crustaceans. The coprolite preservation was good at this site. One of the coprolites was positive for $E$. vermicularis eggs.

The excavation of 4 sites affiliated with the Chiribaya culture of the Moquegua River Valley of southern Peru by Buikstra and colleagues [15] resulted in the recovery of mummies and coprolites. The 4 sites were San Geronimo, Chiribaya Alta, Chiribaya Baja, and Yaral. Intestinal contents from mummies were analyzed for Chiribaya Alta. Coprolites not associated with mummies were recovered from Chiribaya Baja and San Geromino. The sites were distributed from the coast (San Geronimo) to the lower valley agricultural areas (Chiribaya Alta and Chiribaya Baja) to the middle valley (Yaral). One coprolite from Chiribaya Baja was recovered in a later excavation by Sonia Guillén. Analysis of intestinal contents from the mummies revealed 1 possible E. vermicularis infection. However, the possible eggs were very poorly preserved. Therefore, our diagnosis in this case was not secure. Guillén's excavations resulted in the recovery of a coprolite from a unique context. The coprolite was found on the face of a mummy. A person in prehistory entered the tomb, opened the mummy bundle, and deposited feces on the mummy's face. This represents an interesting prehistoric episode. This case of a fecal deposit on this mummy is interesting parasitologically because the coprolite on the face contained many Enterobius eggs (1,200 eggs per gram) and is the only coprolite from the valley that exhibits $E$. vermicularis infection. The coprolites from house contexts at San Geronimo and Chiribaya Baja, though positive for other helminth species, were negative for E. vermicularis. A second study focused on a different set of coprolites from the sites of San Geronimo and Chiribaya Baja [16].

We examined 40 coprolites from the Paloma Site located on the central coast of Peru (unpublished data). Radiocarbon dates for the site center around 6,000 years ago $[8,10]$. This is an open site and coprolite preservation was particularly bad. We selected 20 coprolites from diverse contexts, including burials for analysis. None of these were positive for helminth eggs.

The Ring Site, an open shell mound in southern Peru [8], was visited by Reinhard in 1990. The site dates to 7,67510,575 B.P. He recovered 6 coprolites from the stratigraphic profile left open from previous excavations [9]. There was very little organic residue remaining in the coprolites other than fish bone and small numbers of pollen grains. Pinworm eggs are the most delicate of human parasites recovered from archaeological sites. This site was not conducive to the preservation of such delicate structures. It is likely that any eggs that were in the feces at the time of defecation decomposed over the passage of millennia. No pinworm eggs were recovered from the Ring Site. The site was largely destroyed by construction [10].

From the Caserones site in the Tarapacá Valley, northern Chile, 20 coprolites were analyzed [17]. The site is dated by radiocarbon technique to 2,400-1,200 years ago. The coprolites are from an agricultural period. Preservation of the coprolites was excellent. One coprolite was positive for pinworm eggs.

The examination of coprolites from the site of Tulán near San Pedro de Atacama, Chile was interesting because it represents a prehistoric population with a mixed subsistence of farming and llama herding and also because the site is located far from the Pacific coast [18]. The site is dated by radiocarbon technique between 3,080 and 2,950 years ago. The coprolites were fragmented. Of 16 samples analyzed, 11 were positive for E. vermicularis eggs. The sampling strategy was not known to the parasitologists, so it was impossible to be certain of how many defecations or individuals were represented. The high number of positive samples suggested multiple sampling of several fragments from positive coprolites.

Ferreira and colleagues [19] analyzed 26 coprolites from the 
site of Tiliviche in northern Chile. This is one of the oldest dated Atacama Desert sites, with a beginning date of 9,810 years ago. Two occupational strata contained coprolites. The first, Unit I, ranged between 7,900 and 6,110 years ago. A second, more recent occupation, Unit II, had a commencing date of 6,110 years ago and an ending date of 3,950 years ago. The site itself lies $40 \mathrm{~km}$ from the Pacific coast at an altitude $950 \mathrm{~m}$. The nearest modern city in the region is Iquique. Preservation of the coprolites was excellent. The prehistoric subsistence was based on marine animals. No E. vermicularis eggs were found.

We recently analyzed 21 mummies excavated from coastal sites in northern Chile from the site of Morro 1 and Morro 1-6, Arica, Chile. These mummies were associated with the Chinchorro Culture of 6,000 to 4,000 B.P. and are dated by radiocarbon technique to a period around 4,000 years ago. Subsistence was based on terrestrial plants and marine animals. The coprolites recovered from the mummies were well preserved. No pinworm eggs were found, although another helminth species was present (unpublished data).

The examination of 15 pre-Inca coprolites and 20 Inca coprolites from Calogero Santoro's excavations of farming sites in the Lluta Valley of Chile revealed an interesting difference in Enterobius sp. infection [20]. None of the pre-Inca coprolites were positive for pinworm, although other helminth species were present. Of the 20 Inca coprolites, 5 were positive. Both collections of coprolites came from diverse contexts. Both collections exhibited excellent preservation, and both collections are finely dated by radiocarbon technique and artifact association. The change in settlement pattern may explain the increase in pinworm infections. Prior to the Inca, farmers lived in dispersed communities. The Inca moved farmers to central villages, thus crowding the population.

The analysis of an Argentinian frozen child sacrificed by the Incas revealed pinworm infection [21]. Another analysis of a Chilean Inca sacrifice was done by Horne [22]. The latter individual was not positive for pinworm eggs.

For this study, we examined 45 coprolites from mummies from San Pedro de Atacama that were archived in the human coprolites repository at the Laboratory of Paleoparasitology Collection (ENSP-Fiocruz). These mummies date as old as 2,000 years ago and from different cultures. Also from the ENSP-Fiocruz collections, we analyzed 48 coprolites from Antofogasta, Chile. No eggs of E. vermicularis were encountered (unpublished data).

Araújo completed a study of coprolites from southeastern
Brazil. These new data are summarized in Table 2. Gruta do Gentio II is found at Unaí in the northwest of the state of Minas Geris, Central Brazil [23]. The cave is located in a calcareous bank $2.5 \mathrm{~km}$ long. The entrance is about $6 \mathrm{~m}$ above soil level and its main chamber measures $10 \mathrm{~m} \times 14 \mathrm{~m}$ and is about $3 \mathrm{~m}$ high, close to the entrance. This site was used by prehistoric people as a habitation and served also as a burial place. Wooden art objects, feathers, snail shells, and food remains (e.g. peanut and maize) were found in the different strata. The layers are dated by C14 method and has 2 occupation layers, the deepest (oldest dating 8,620 \pm 100 years B.P.) corresponding to groups of hunter-gatherers, and the upper $(3,490 \pm 120$ to $430 \pm 70$ years B.P.) to groups showing agricultural activities. Coprolites were collected in the upper layer, and the positive samples may be up to 3,610 years old and have a minimum age of 360 years. A mummified body of a child was also found in the cave and was dated to 2,850 years old [24]. Although 20 coprolites were initially analyzed from this site [25], 278 coprolite fragments were ultimately analyzed by Araújo. They were in variable states of preservation. Although they were positive for other helminth species, they were negative for pinworm.

The site of Boqueirão Soberbo, Varzelândia, Minas Gerais, is a rock-shelter in a calcareous bank, measuring $14 \mathrm{~m} \times 9.5 \mathrm{~m}$, and $8 \mathrm{~m}$ high [23]. The cave was used as a burial place, and there are rock paintings on the walls. The culture was identified as hunter-gatherers. Dates of 4,905 \pm 90 years ago (SI2789 ) to $1,325 \pm 60$ years ago (SI-4486) were obtained for this site. Two human coprolites were recovered from this site. Although positive for other helminths, they were negative for pinworms [26]. A partially mummified individual from Lapa do Boquete was negative for pinworms but positive for other parasites [27].

Parasitological analyses have also been done in the northeast of Brazil. The site of Boqueirão de Pedra Furada is a widely published site because of the purported antiquity of its deepest layers [23]. It has a sheltered area within it, formed by ancient rockfalls. Within this sheltered area, protected from the actions of water, archaeological deposits accumulated. Coprolites were recovered from a higher and more recent stratum dated by radiocarbon analysis to $7,230 \pm 80$ years ago. Seventeen coprolites from this area have been analyzed $[26,28]$. Although they were positive for other helminths, they were negative for pinworms. 


\section{North America}

The archaeoparasitology of North America and descriptions of sites have been presented in several over-view articles $[5,29,30]$. Therefore, the sites from North America will be presented here by culture and subsistence type.

Several caves containing hunter-gatherer coprolites have been excavated. The sites have been excavated throughout the arid west of North America, especially in the Great Basin, with some excavations in the Colorado Plateau, and the Chihuahua Desert of Texas and Mexico. These include Danger Cave and Hogup Cave in Utah, Dust Devil Cave and Bighorn Cave in Arizona, Lovelock Cave in Nevada, Dirty Shame Rockshelter in Oregon, Hinds Cave in Texas, and Frightful Cave in Coahuila, Mexico [30]. The caves are dated chronometrically, and the sampling strategies optimized diversification by sampling coprolites from different stratigraphic layers separated by many years of deposition. Coprolite preservation is excellent for all of these sites. Generally, E. vermicularis eggs are rare in these hunter-gatherer sites $[7,30]$. However, the oldest coprolites studied from Danger Cave dated to 10,000 years ago contained eggs [30]. Pinworm eggs have been found in Archaic deposits at Hinds Cave, Hogup Cave, and Dirty Shame Rockshelter (Table 3).

Many sites affiliated with the Ancestral Pueblo (Anasazi) culture have been excavated [30]. The Ancestral Pueblo were an agricultural group that had a mixed subsistence based on domesticated plants and animals with wild plants and animals. Parasite analysis has been completed for coprolites recovered from several sites on Mesa Verde, Colorado, and Glen Canyon, Utah. Analyses have also been completed for Bighorn Sheep Cave and Turkey Pen Cave in the Grand Gulch of Utah, Antelope House in Canyon del Muerto of Arizona, Pueblo Bo-

Table 3. Dates for Enterobius vermicularis analyses from North America

\begin{tabular}{|c|c|c|c|}
\hline Locality & Reference & No. studied/No. positive & Dates (B.P.) \\
\hline Paisley Cave, Oregon & {$[47]$} & $23 / 0$ & 9,620 \\
\hline Danger Cave, Utah & [30] & $46 / 1$ & $10,000-9,000$ \\
\hline Dust Devil Cave, Arizona & [30] & $100 / 0$ & $9,975-8,500$ \\
\hline Dirty Shame Shelter, Oregon & [30] & $13 / 1$ & $6750-8250$ \\
\hline Frightful Cave, Coahuila, Mexico & [30] & $32 / 0$ & $7,000-4,000$ \\
\hline Hogup Cave, Utah & [30] & $50 / 4$ & $5960 ; 3,200 ; 1,600$ \\
\hline Hinds Cave, Texas & [30] & $117 / 1$ & $4,100-2,600$ \\
\hline Upper Salts Cave, Kentucky & [48] & $8 / 0$ & $2,600-2240$ \\
\hline Big Bone Cave, Tennessee & [37] & $8 / 5$ & 2,200 \\
\hline Bighorn Cave, Arizona & [30] & $35 / 0$ & $2,200-1,600$ \\
\hline Turkey Pen Cave, Utah & [30] & $24 / 7$ & $2,050-1,775$ \\
\hline Love Lock Cave, Nevada & [30] & $50 / 0$ & 1,830 \\
\hline Antelope House, Arizona & [30] & $180 / 44$ & 1,400; 925; 860 \\
\hline Rio Zape, Durango, Mexico & {$[33,34]$} & $100 / 23$ & 1,400 B.P. \\
\hline Canyon del Muerto & {$[31]$} & $2 / 1$ & "Puebloan" \\
\hline Antelope Cave, Arizona & [36] & $22 / 4$ & 1,100 \\
\hline Skiles Mummy, Texas & [49] & $1 / 0$ & 1250 \\
\hline Clyde's Cavern, Utah & [30] & $24 / 4$ & $1,500-800$ \\
\hline Pueblo Bonito, New Mexico & [30] & $15 / 4$ & $920-870 ; 1,080-980$ \\
\hline Kin Kletso, New Mexico & [30] & $5 / 0$ & $1,000-1,100$ \\
\hline Mesa Verde, Colorado & [30] & $76 / 5$ & $1,000-800$ \\
\hline Bighorn Sheep Ruin & [30] & $20 / 2$ & $950-850$ \\
\hline Salmon Ruin, New Mexico & [30] & $112 / 9$ & $900-750$ \\
\hline Ventana Cave, Arizona & [50] & $1 / 0$ & $950-500$ \\
\hline Inscription House, Arizona & [30] & $17 / 3$ & $750-700$ \\
\hline Glen Canyon, Utah Pueblo & [30] & $20 / 0$ & $900-1,100$ \\
\hline Glen Canyon, Utah Fremont & [30] & $10 / 0$ & $900-1,100$ \\
\hline Qilakitsoq, Greenland & [51] & $1 / 1$ & 475 \\
\hline Total & positive s & ,112 samples fro & \\
\hline
\end{tabular}

Dating has been converted to the Before Present (B.P.) scale. By archaeological and geological convention, January 1, 1950 is the modern reference point for this scale. 


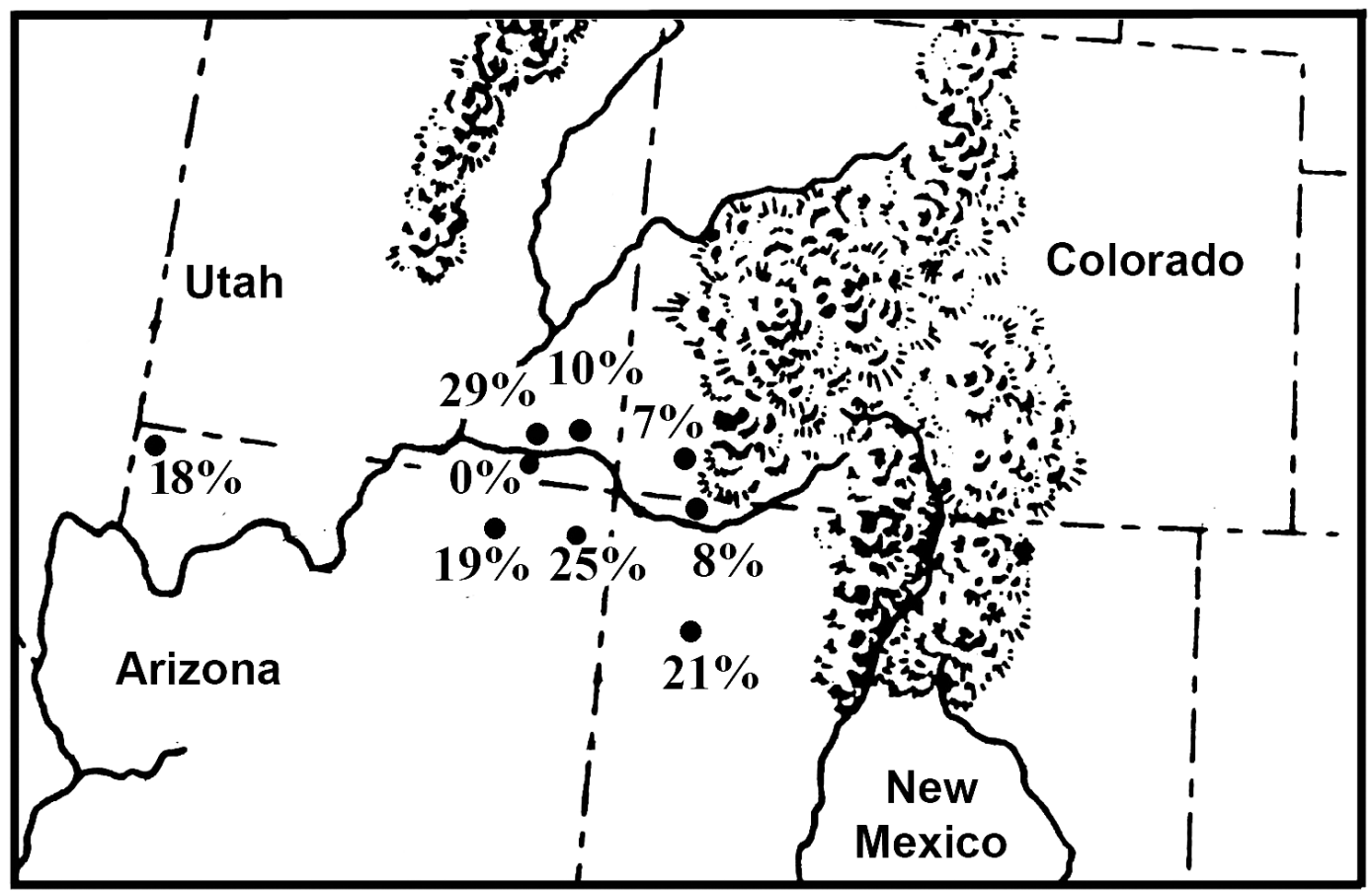

Fig. 1. Prehistoric coprolites from Ancestral Pueblo sites show variability of pinworm prevalence. The percent of coprolites positive for parasite eggs are as follow: 0\% Glen Canyon sites, Utah; 7\% Mesa Verde, Colorado; 8\% Salmon Ruin, New Mexico; 10\% Bighorn Sheep Ruin, Utah; 18\% Antelope Cave, Arizona; 19\% Inscription House, Arizona; 21\% Chaco Canyon sites, New Mexico; 25\% Antelope House, Arizona; 29\% Turkey Pen Cave, Utah.

nito and Kin Kletso in Chaco Canyon, New Mexico, Inscription House in the Navajo National Monument of Arizona, and Salmon Ruin on the San Juan River, New Mexico (Fig. 1). Coprolite preservation is excellent for most sites. The sampling strategies were well diversified for most sites [30]. The coprolites from Chaco Canyon were badly preserved and fragmented. E. vermicularis is nearly ubiquitous for Ancestral Pueblo sites and is very common in coprolites from Antelope House and Turkey Pen Cave (Table 3). The analysis of 2 Ancestral Pueblo mummies revealed 1 infection with pinworm [31]. Fugassa and colleagues [32] analyzed Ancestral Pueblo coprolites from Antelope Cave at the edge of the Great Basin in northwestern Arizona. They found that pinworms had a high prevalence at the site.

One site from the Sinagua Culture in central Arizona has been studied [33]. Coprolites were not recovered from this site. The analysis was done with sediments from ancient latrines. E. vermicularis eggs were recovered from these sediments in association with 4 other helminth species.

Several sites of the Fremont culture have been excavated and analyzed for parasite eggs [30]. The Fremont culture occupied much of Utah in prehistory. There was a variety of subsistence strategies carried out by the Fremont. Maize was grown to some extent in the southern parts of the range. However, in central Utah, the subsistence patterns are poorly defined. From Clyde's Cavern in central Utah, 25 coprolites were studied. Four contained pinworm eggs. From southern Utah, 10 Fremont coprolites from Glen Canyon were studied. None were positive for helminths. Dating methods, sampling strategy and preservation are not known to us for Clyde's Cavern. The preservation, dating, and sampling strategy is good for Glen Canyon [30].

Coprolites from La Cueva de los Muertos Chiquitos in Rio Zape, Durango, Mexico, were analyzed in 3 separate studies $[34,35]$. Dietary analysis of 50 coprolites showed a diverse array of foods, and each coprolite was distinct in its macroscopic and microscopic constituents [36]. Meade observed pinworm eggs in his study of dietary residues. A second study of 36 coprolites by Jiménez and colleagues [34] documented a high prevalence of pinworms. Finally, Morrow [35] recovered pinworm eggs from 34 of the 100 coprolites analyzed.

Outside of the desert west of the USA, pinworm has been found in the Southeastern USA in coprolites [37]. 


\section{DISCUSSION}

There is a sharp contrast in pinworm prevalence between early and late prehistory in North America. For most of prehistory in the Americas, pinworm infection was relatively rare. Of Archaic sites from North America, 4 of 8 show low prevalence of infection. In contrast, almost all studies of later ceramic, agricultural sites dating after 1,600 years ago from North America show moderate to high infection prevalence. This includes the southeastern area of the USA where Faulkner and colleagues report a high prevalence of infection at Big Bone Cave, Tennessee [37].

In South America, no positive coprolites have been found in Brazil. Of the 14 studies from Peru and Chile, 6 showed good evidence of E. vermicularis infection, and 5 of these date to relatively late, agricultural sites. These data indicated that $E$. vermicularis was relatively rare before agriculture was established, similar to the evidence from North America.

Among Ancestral Pueblo and Archaic populations in North America, there is noteworthy variance in the prevalence of coprolites positive for Enterobius eggs as previously published by Hugot et al. [38]. Forager (hunter-gatherer) sites were occupied by small groups of people (less than 50) who subsisted on wild plants and animals. Agricultural sites were occupied by large groups of people (up to several hundred) who subsisted in part on cultivated plants and in part on wild plants and animals. The lowest prevalence of E. vermicularis eggs is evident at hunter-gatherer cave sites (2\%). Stone walled agricultural villages not associated with caves have a prevalence of $10 \%$. Statistical evaluation of these data indicates a significant increase in egg prevalence in agriculturalists over hunter-gatherers $(P<0.001)$. Each of these stone walled villages (Salmon Ruin, Kin Kletso, and Pueblo Bonito) is large, multi-storied villages that contain from 200 to 500 rooms. They represent the largest villages built in the Southwest before $1300 \mathrm{AD}$ [42].

Higher prevalences of coprolites positive for $E$. vermicularis (19\%) is evident among samples from Ancestral Pueblo stonewalled villages built in caves [38]. These villages are multi-storied, but the size of the villages are constrained by the size of the caves in which they are built. Comparison of pinworm prevalence between stone-walled villages outside of caves and stone-walled villages within caves showed an increase in egg prevalence in coprolites in caves, but was not statistically significant [38].

It is apparent that 2 aspects of behavior, subsistence type and dwelling type, affected pinworm prevalence [38]. These 2 aspects are not independent [39]. Hunter-gathering subsistence limits population size to no more than 50 people. Especially in arid lands, carrying capacity prevents the development of large numbers of hunter-gatherers. Also, because huntergatherers must frequently move from one area to another to find food, the development of permanent structures in arid lands is unknown. These are factors that ultimately define the nature of hunter-gatherer parasitism, especially with regard to low pinworm prevalence [39].

The development of agriculture had significant impacts on habitation type and population size [39]. A dependable, storable food supply led to the increase of populations such that hundreds to thousands of people lived together. The need to store food, and need to defend arable land, necessitated the establishment of permanent villages. These aspects of agricultural life led to an impressive change in the nature of human parasitism as documented by coprolite study [39]. In the arid west of North America, many of the permanent villages were established in caves.

The increase in pinworm prevalence in coprolites between agricultural people and hunter-gatherers is related to population size. This is evident by the highly significant increase in pinworm positive coprolites from stone-walled villages not associated with caves over the hunter-gatherer samples. This is probably due to the increased chance of transmission of pinworms in larger populations. However, there is an interesting, although not statistically significant, increase in pinworm positive coprolites in villages within caves. This indicates that population size is not the only variable that led to increased pinworm infection since it is unlikely that populations were larger or more concentrated in caves. Indeed, analyses of room patterns between cave villages and open villages indicated that the basic organization of open villages was the same as in caves. Therefore, there must be some other factor involved.

More recent studies present further evaluations of how infection would have occurred in crowded conditions in large villages and towns $[5,29,36,41,42]$. One distinct difference between caves and open villages is the fact that airflow is limited within the confines of a cave. This allows airborne particles to remain in the air column for a longer period of time which in turn increases the chances of encounter with humans living in the cave. Enterobius sp. eggs are infective through inhalation $[38,40-42]$. The still air of caves enhances the potential of human infection with pinworms. Thus, for agriculturalists who 
built their villages in caves, the interplay of larger population combined with poor air circulation led to the increase of pinworm infection, which is reflected by greater numbers of coprolites that are positive for pinworm eggs. It is noteworthy that in comparison to other countries in which extensive coprolite studies have been performed, such as Chile, Peru, and Brazil, only in the cave village sites in the Southwest USA and arid Mexico does pinworm reach such a high prevalence.

Fugassa and colleagues [36] found a high (18\%) infection level for coprolites excavated from Antelope Cave, Mojave County, Arizona. This cave was used for storage and seasonal rabbit hunting. Unlike other Ancestral Pueblo people from the Southwest living around 1,000 years ago, large villages are unknown in the Antelope Cave area. Virgin River Puebloans lived in small, seasonal pueblo groups of only a few rooms [43]. It is likely that infection was aggravated by activities in caves where eggs passed by even a few people would have had an optimal chance of being inhaled by uninfected people.

When one considers that only 1 in 20 people infected with pinworm will pass eggs in feces, the Southwestern USA and Mesoamerican data would show that the development of villages raised the potential of pinworm exposure to extreme levels. For stone-walled villages away from caves, 1 in 10 coprolites are positive for eggs. For stone-walled villages in caves, 1 in 5 coprolites are positive for eggs. Indeed, for agricultural cave sites, the coprolite data suggest that infection was unavoidable. The data for Puebloan prevalence is presented in Fig. 1 and ranges from $0 \%$ to $29 \%$. The data represent the number of pinworm positive samples in diversified samples. The lowest prevalence is represented by Glen Canyon (0\%). One of us, Reinhard, excavated sites in this region for 1 field season. Ecologically, the region is very arid with few smaller rock shelters. Small villages, probably for single extended families, were constructed in the open and also in rock shelters. The population size, aridity, and relatively small shelters would not have been conducive to pinworm transmission. Mesa Verde has a prevalence of $7 \%$. This high altitude and colder area has many large rockshelters. Villages are larger and some are built in rockshelters. Therefore, the increase in prevalence is understandable.

The wide range for large, open towns represented by Salmon Ruin (8\%) and Chaco Canyon (21\%) was addressed in detail [42]. These types of sites are called Great Houses by archaeologists due to their large floor plan and multiple store construction. One of us, Reinhard, excavated at Salmon Ruins and sur- veyed many other Great Houses. They were used as ceremonial centers (Chaco Canyon) and habitations (Salmon Ruin). Reinhard addressed the variation in prevalence based on 3 years of field work in the region followed by 6 years of lab analysis of coprolites from these sites [42]. He concluded that activity spaces were used differently with more rooftop and plaza use at Salmon Ruin. The larger population sizes attracted to Chaco Canyon would have increased the prevalence of pinworms, which are crowd parasites.

In the Grand Gulch of Utah, data are available for one of the oldest agricultural sites, Turkey Pen Cave (29\%), and the later Bighorn Sheep Ruin (10\%). Both are relatively large sites. Bighorn Sheep Ruin has 28 structures in a rock shelter and is the second largest pueblo in the area. The wide variation between these sites in prevalence is surprising. The higher prevalence in the earlier context is ambiguous.

Extremes in environment can be found in Arizona. In the Kayenta area of northeastern Arizona, Inscription House (19\%) and Antelope House (25\%) are large pueblo towns built in rockshelters. An analysis of Antelope House shows that this was an especially crowded site [5]. The high prevalence of pinworm coincided with the highest diversity of parasites ever recorded at a Puebloan site. Another site in the opposite corner of Arizona is Antelope Cave (18\%). This northwestern site is near the Virgin River, which gives its name to the culture of the region, the Virgin River Puebloans [43]. This is a true cave, being deeper than wide and with a small entrance. As noted above, the villages for the Virgin River Puebloans were small and dispersed. Therefore, crowding did not contribute to the transmission of pinworm. It is likely that seasonal use of deep caves promoted airborne infection within the caves.

The unavoidable nature of pinworm infection is understandable in the context of the evolution of the E. vermicularis life cycle. The aerosol mode of contamination evolved during a stage in evolution at which anal-oral infection became tenuous. Therefore, the parasite evolved a more efficient system of infection in context with the evolutionary changes in the morphology and behavior of its host. This adaptation allowed the parasite to continue to cycle in humans. However, human behavioral evolution continued. Ultimately, the result of behavioral evolution was the development of crowded, sedentary habitations such as those represented by the sites summarized above. In these artificial environments, the aerosol transmission of pinworm resulted in very high rates of infection. Thus, the emergence of Enterobius sp. as one of the most ubiquitous 
of human parasites today relates directly to the adaptation of this species to evolving humans in antiquity.

In summary, pinworms migrated into the Americas with relatively small bands of hunter-gatherers. Pinworms have been found in archaeological contexts in the arctic [51]. This demonstrates that pinworms persisted in cold conditions. Indeed, the crowded winter habitations in the arctic would have exacerbated transmission of pinworms, which are one of the most highly infective helminths. Studies of recent arctic populations verified that pinworm cycles among people in the coldest climates [52]. There can be no doubt that pinworm entered the Americas in every migration route taken by humans in prehistory [53]. As pointed out in a recent review of pinworm evolutionary history, infection is not dependent on climate conditions.

At this point, the archaeological data show that pinworm infection persisted in dilute hunter-gatherers, spread throughout the desert west of North America, and then moved deep into the Andes of South America. The absence of pinworm in Brazil is puzzling. Continued analysis of Brazilian remains is needed to determine if this is an aspect of taphonomy, sample size, or if it reflects a real exclusion of pinworm from this large region.

Because pinworm is present archaeologically in most regions of the Americas, molecular analysis provides a potential of documenting multiple migrations and genetic isolation of peoples in prehistory [53-55]. More than most parasite lineages, pinworm phylogeny shows tight congruence with primate phylogeny $[38,56-58]$. This shows that cospeciation and coevolution occurred between pinworms and their primate hosts. Within just the human species, genetic drift occurs in pinworms in separate human populations. This resulted in the evolution of at least 1 new species, E. gregorii, in humans in Europe, Africa, and Asia [42]. Genetic drift occurred in prehistoric pinworms in different parts of the Americas, which has also been demonstrated $[43,44]$. These studies showed that different humans, using different migration routes to the Americas, carried genetically distinct pinworm populations. Thus, a Beringian migration might have brought a different pinworm genotype relative to humans migrating with parasites from different regions. Two different $E$. vermicularis genetic sequences have been found in prehistoric coprolites from the Americas. We encourage experienced paleo DNA experts to explore the DNA of pinworms to add information relevant to our understanding of the first migrations of prehistoric hu- mans to the Americas.

\section{ACKNOWLEDGMENTS}

The writing of this manuscript and the research in Brazil, including analysis of Peruvian and Chilean coprolites, was funded by the Brazilian National Council for Scientific and Technological Development (CNPq) and the Improving Coordination of Higher Education Personnel (CAPES) and the Fulbright Commission Debra K. Meier prepared Fig. 1.

\section{CONFLICT OF INTEREST}

We declare that we have conflict of interest related to this work.

\section{REFERENCES}

1. Camacho M, Araujo A, Morrow JJ, Reinhard KJ. Recovering parasites from mummies and coprolites: establishing an epidemiological approach. Int J Paleopathol 2016 (in press).

2. Reinhard KJ, Bryant VM. Coprolite analysis: a biological perspective on archaeology. In Schiffer MB ed, Advances in Archaeological Method and Theory 4. Tucson, USA. University of Arizona Press. 1992, pp 245-288.

3. Reinhard KJ. Reestablishing rigor in archaeological parasitology. Int J Paleopathol 2016 (in press).

4. Chame M. Terrestrial mammal feces: a morphometric summary and description. Mem Inst Oswaldo Cruz 2003; 98 (suppl 1): 71-94.

5. Reinhard KJ. Pathoecology of two Ancestral Pueblo villages. In Reitz EJ, Scarry CM, Scudder SJ eds, Case Studies in Environmental Archaeology, 2nd ed. New York, USA. Plenum Press. 2008, pp 191-210.

6. Dean GW. The science of coprolite analysis: the view from Hinds Cave. Palaeogeogr Palaeoclimatol Palaeoecol 2006; 237: 67-79.

7. Reinhard KJ, Ambler JR, McGuffie M. Diet and parasitism at Dust Devil Cave. Am Antiq 1985; 50: 819-824.

8. Benfer RA. Early villages. In Pearsall DM ed, Encyclopedia of Archaeology. New York, USA. Academic Press. 2008, pp 368-380.

9. Sandweiss DH, Richardson III JB, Reitz EJ, Hsu JT, Feldman RA. Early maritime adaptations in the Andes: preliminary studies at the Ring Site, Peru. In Rice DS, Stanish C, Scar PR eds, Ecology, Settlement, and History in the Osmore Drainage, Peru: BAR International Series 545. Oxford, UK. British Archaeological Reports. 1989, pp 35-84.

10. Moore JD. A Prehistory of South America: Ancient Cultural Diversity on the Least Known Continent. Boulder, USA. University Press of Colorado. 2014, p 560.

11. Morrow JJ, Newby J, Piombino-Mascali D, Reinhard KJ. Tapho- 
nomic considerations for the analysis 1 of parasites in archaeological materials. Int J Paleopathol 2016, 13: 56-64.

12. Rácz $\mathrm{SE}$, De Araújo $\mathrm{EP}$, Jensen $\mathrm{E}$, Mostek $\mathrm{C}$, Morrow JJ, Van Hove ML, Bianucci R, Willems D, Heller F, Reinhard KJ. Parasitology in an archaeological context: analysis of medieval burials in Nivelles, Belgium. J Archaeol Sci 2015; 53: 304-315.

13. Callen EO, Cameron TW. A prehistoric diet revealed in coprolites. New Sci 1960; 8: 35-40.

14. Patrucco R, Tello R, Bonavia D. Parasitological studies of coprolites of pre-Hispanic Peruvian populations. Curr Anthropol 1983; 24: 393-394.

15. Martinson E, Reinhard KJ, Buikstra JE, Cruz KD. Pathoecology of Chiribaya parasitism. Mem Inst Oswaldo Cruz 2003; 98: 195205.

16. Holiday DM, Guillen S, Richardson DJ. Diphyllobothriasis of the Chiribaya culture (700-1476 AD) of southern Peru. Comp Parasitol 2003; 70: 167-171.

17. Iñiguez AM, Araujo A, Ferreira LF, Vicente AC. Analysis of ancient DNA from coprolites: a perspective with random amplified polymorphic DNA-polymerase chain reaction approach. Mem Inst Oswaldo Cruz 2003; 98: 63-65.

18. Ferreira LF, Araujo A, Confalonieri U, Nuñez L. Infecção por Enterobius vermicularis em populações agropastoris pré-columbianos de San Pedro de Atacama, Chile. Mem Inst Oswaldo Cruz 1989; 84: 197-199.

19. Ferreira LF, de Araujo AJ, Confalonieri UE, Nuñez L. The finding of eggs of Diphyllobothrium in human coprolites (4,100-1,950 B.C.) from northern Chile. Mem Inst Oswaldo Cruz 1984; 79: 175-180.

20. Santoro C, Vinton SD, Reinhard KJ. Inca expansion and parasitism in the Lluta Valley: preliminary data. Mem Inst Oswaldo Cruz 2003; 98: 161-163.

21. Zimmerman MR, Morilla RE. Enterobiasis in pre-ColumbianAmerica. Paleopathol News 1983; 42: 8.

22. Horne PD, Kawasaki SQ. The Prince of El Plomo: a paleopathological study. Bull N Y Acad Med 1984; 60: 925-931.

23. Araujo AGM, Piló LB, Neves WA, Atui JPV. Human occupation and paleoenvironments in South America: expanding the notion of an "Archaic Gap". Rev Mus Arqueol Etnol São Paulo 20052006; 15-16: 3-35.

24. Ferreira LF, de Araujo A, Confalonieri UE. The finding of helminth eggs in a Brazilian mummy. Trans R Soc Trop Med Hyg 1983; 77: 65-67.

25. Ferreira LF, de Araujo AJ, Confalonieri UE. The finding of eggs and larvae from parasitic helminths in archaeological material from Unaí, Minas Gerais, Brazil. Trans R Soc Trop Med Hyg 1980; 74: 798-800.

26. Gonçalves ML, Araújo A, Ferreira LF. Human intestinal parasites in the past: new findings and a review. Mem Inst Oswaldo Cruz 2003; 98: 103-118.

27. Sianto L, Reinhard KJ, Chame M, Chaves S, Mendonça S, Gonçalves ML, Fernandes A, Ferreira LF, Araújo A. The finding of Echinostoma (Trematoda: Digenea) and hookworm eggs in cop- rolites collected from a Brazilian mummified body dated 6001.200 years before present. J Parasitol 2005; 91: 972-975.

28. Ferreira LF, Araujo A, Confalonieri U, Chame M, Riberiofilho B. Encontro de ovos de ancilostomideos em coprólitos humanos datados 7230 \pm 80 anos. An Acad Bras Ciênc 1987; 59: 280-281.

29. Reinhard KJ, Bryant VM. Pathoecology and the future of coprolite studies in bioarchaeology. In Stodder AWM ed, Reanalysis and Reinterpretation in Southwestern Bioarchaeology. Tempe, USA. Arizona State University Press. 2008, pp 199-216.

30. Reinhard KJ. The impact of diet, and parasitism on anemia in the prehistoric west. In Stuart-McAdam P, Kent S eds, Diet, Demography and Disease: Changing Perspectives of Anemia. New York, USA. Aldine de Gruyter. 1992, pp 219-258.

31. El-Najjar MY, Benitez J, Fry G, Lynn GE, Ortner DJ, Reyman TA, Small PA. Autopsies on two native American mummies. Am J Phys Anthropol 1980; 53:197-202.

32. Fugassa, MH, Reinhard KJ, Johnson KL, Gardner SL, Vieira M, Araújo A. Parasitism of prehistoric humans and companion animals from Antelope Cave, Mojave County, northwest Arizona. J Parasitol 2011; 97: 862-867.

33. Reinhard KJ, Hevly RH, Anderson GA. Helminth remains from prehistoric Indian coprolites on the Colorado Plateau. J Parasitol 1987; 73: 630-639.

34. Jiménez FA, Gardner SL, Araújo A, Fugassa M, Brooks RH, Rácz E, Reinhard KJ. Zoonotic and human parasites of inhabitants of Cueva de Los Muertos Chiquitos, Rio Zape Valley, Durango, Mexico. J Parasitol 2012; 98: 304-309.

35. Morrow JJ. Exploring Parasitism in Antiquity through the Analysis of Coprolites and Quids from La Cueva de los Muertos Chiquitos, Rio Zape, Durango, Mexico (Ph.D. dissertation). School of Natural Resources, University of Nebraksa-Lincoln. 2016.

36. Hammerl EE, Baier MA, Reinhard KJ. Agave chewing and dental wear: evidence from quids. PLoS One 2015; 10: e0133710.

37. Faulkner CT, Patton S, Johnson SS. Prehistoric parasitism in Tennessee: evidence from the analysis of desiccated fecal material collected from Big Bone Cave, Van Buren County, Tennessee. J Parasitol 1989; 75: 461-463.

38. Hugot JP, Reinhard KJ, Gardner SL, Morand S. Human enterobiasis in evolution: origin, specificity and transmission. Parasite 1999; 6: 201-208.

39. Reinhard KJ. The cultural ecology of prehistoric parasitism on the Colorado Plateau as evidenced by coprology. Am J Phys Anthropol 1988; 77: 355-366.

40. Hugot JP, Tourte-Schaffer C. Etude morphologique des oxyures parasites de l'homme: Enterobius vermicularis and E. gregorii. Ann Parasitol Hum Comp 1985; 60: 57-64.

41. Reinhard KJ, Pucu E. Comparative parasitological perspectives on paleoepidemiological transitions: Americas and Europe. In Zuckerman MK ed, Moving the Middle to the Foreground: Interdisciplinary Approaches to Examining the Second Epidemiological Transition. Hoboken, USA. Wiley-Blackwell. 2014, pp 311326.

42. Reinhard K. Parasite pathoecology of Chacoan Great Houses: 
the healthiest and wormiest Ancestral Puebloans. In Reed PF ed, Chaco's Northern Prodigies Salmon, Aztec, and the Ascendancy of the Middle San Juan Region after AD 1100. Salt Lake City, USA. University of Utah Press. 2008, pp 86-95.

43. Lyneis MM. The Virgin Anasazi, far western puebloans. J World Prehist 1995; 9: 191-241.

44. Allison MJ, Pezzia A, Hasegawa I, Gerszten E. A case of hookworm infestation in a pre-Columbian American. Am J Phys Anthropol 1974; 41: 103-106.

45. Pizzi T, Schenone H. Hallazgo de huevos de Trichuris trichiura en contenido intestinal de un cuerpo arqueológico incaico. Bol Chil Parasitol 1954; 9: 73-75.

46. Fouant MM, Allison M, Gerszten E, Focacci AG. Parasitos intestinales entre los indigenas precolombinos. Chungara 1982; 9: 285-299.

47. Jenkins DL, Davis LG, Stafford Jr TW, Campos PF, Connolly TJ, Cummings LS, Hofreiter M, Hockett B, McDonough K, Luthe I, O'Grady PW, Reinhard KJ, Swisher ME, White F, Yates B, Yohe RM, Yost C, Willerslev E. Geochronology, Archaeological Context, and DNA at the Paisley Caves. In Graf KE, Ketron CV, Waters MR eds, Paleoamerican Odyssey. College Station, USA. Texas A\&M University Press. 2013, pp 485-510.

48. Fry GF. Ovum and Parasite Examination of Salts Cave Human Paleofeces. In Watson PJ ed, Archeology of the Mammoth Cave Area. New York, USA. Academic Press. 1974, p 61.

49. Reinhard K, Fink TM, Skiles J. A case of megacolon in Rio Grande Valley as a possible case of Chagas Disease. Mem Inst Oswaldo Cruz 2003; 98 (suppl 1): 165-172.

50. Reinhard KJ, Hevly RH. Dietary and parasitological analysis of mummy 5, Ventana Cave, Arizona. Kiva 1991; 56: 319-325.

51. Lorentzen B, Rørdam AM. Investigation of faeces from a mummified Eskimo woman. In Hart Hansen JP, Gullov HC eds, The
Mummies from Qilaleitsoq: Eskimos in the 15th Century. Copenhagen, Denmark. Kommissionen for Videnskabelige Undersøgelser i Grønland. 1989, pp 139-143.

52. Brown M, Sinclair RG, Cronk LB, Clark GC, Kuitunen-Ekbaum E. Intestinal parasites of Eskimos on Southampton Island, Northwest Territories. Can J Public Health 1948; 39: 451-454.

53. Araújo A, Reinhard KJ, Ferreira LF, Gardner SL. Parasites as probes for evidence of prehistoric human migrations. Trends Parasitol 2008; 24:112-115.

54. Iñiguez AM, Vicente AC, Araújo A, Ferreira LF, Reinhard KJ. Enterobius vermicularis: specific detection by amplification of an internal region of $5 \mathrm{~S}$ ribosomal RNA intergenic spacer and transsplicing leader RNA analysis. Exp Parasitol 2002; 102: 218-222.

55. Iñiguez AM, Reinhard K, Gonçalves ML, Ferreira LF, Araújo A, Vicente AC. SL1 RNA gene recovery from Enterobius vermicularis ancient DNA in pre-Columbian human coprolites. Int J Parasitol 2006; 36: 1419-1425.

56. Sorci G, Skarstein F, Morand S, Hugot JP. Correlated evolution between host immunity and parasite life histories in primates and oxyurid parasites. Proc Biol Sci 2003; 270: 2481-2484.

57. Hugot, JP. Primates and their pinworm parasites: the Cameron hypothesis revisited. Syst Biol 1999; 48: 523-546.

58. Hugot, JP, Gardner SL, Borba V, Araujo P, Leles D, Stock Da-Rosa ÁA, Dutra J, Ferreira LF, Araújo A. Discovery of a 240 million year old nematode parasite egg in a cynodont coprolite sheds light on the early origin of pinworms in vertebrates. Parasit Vectors 2014; 7: 486 .

59. Teixeira-Santos I, Sianto L, Araújo A, Reinhard KJ, Chaves SA. The evidence of medicinal plants in human sediments from Furna do Estrago prehistoric site, Pernambuco State, Brazil. Quat Int 2015; 377: 112-117. 
